\title{
ORAL MANIFESTATIONS OF ALBRIGHT HEREDITARY OSTEODYSTROPHY: A CASE REPORT
}

\author{
Mônica Fernandes Gomes, Ana Maria Albernaz Camargo, Tatiane Alves Sampaio, \\ Maria Aparecida O. C. Graziozi and Mônica Costa Armond
}

RHCFAP/3088

GOMES MF et al. - Oral manifestations of Albright hereditary Osteodystrophy: a case report. Rev. Hosp. Clín. Fac. Med. S. Paulo 57(4):161-166, 2002.

Albright hereditary osteodystrophy is a hereditary metabolic disorder of dominant autosomal etiology that is commonly characterized by short stature, round face, small metacarpus and metatarsus, mental retardation, osteoporosis, subcutaneous calcification, variable hypocalcemia, and hyperphosphatemia. In this study, we report a clinical case of a 17-year-old woman with Albright hereditary osteodystrophy, and we discuss her clinical, radiographic, and laboratory test characteristics together with the oral manifestations, and we correlate them with the characteristics found in the literature. We also discuss the odontological management of treatment of related periodontal disease and planning for corrections of related malocclusions.

DESCRITORES: Albright's hereditary osteodystrophy. Pseudohypoparathyroidism. Gs protein. Parathormone. Oral manifestations.

\section{INTRODUCTION}

Albright hereditary osteodystrophy (AHO), characterized by a metabolic disorder of dominant autosomal heritage, was first described by Fuller Albright in 1942 and is also called pseudohypoparathyroidism (PHP) or acrodysostosis ${ }^{8,12,16,18,20,21}$

This anomaly is caused by a mutation in the GNAS1 gene in the q13.11 region of chromosome 20 , which results in reduction of quantity and quality $\mathrm{OF}$ the a subunit of the guanine nucleotide regulatory $\mathrm{G}$ protein that is located in cell membranes. The etiopathology of the AHO disease or pseudohypoparathyroidism (PHP) involves the impairing of the functioning of the biochemical pathways responsible for activation of parathormone receptors ${ }^{15,17,19,21}$.

Some intrinsic factors, such as genetic mutation, may cause changes in the a subunit, compromising its function and causing the appearance of metabolic disorders. Such disorders may be expressed clinically as the following diseases: PHP, pseudopseudohypoparathyroidism (PPHP), AHO, acromegaly and hyperfunctional thyroid lymph node and McCuneAlbright syndrome ${ }^{16}$.

Albright hereditary osteodystrophy may be classified as type Ia PHP and

From the Department of Bioscience and Oral Diagnosis and Department of Periodontics and Radiology, São José dos Campos Dental School - São Paulo State University; Department of Radiology, Vale do Rio Verde de Três Corações University and Alfenas University, Campus of Varginha.
PPHP. The first disorder is characterized by a molecular fault in the a subunit of the Gs protein, interrupting the action of parathormones, thyroid stimulants, and gonadotrophins, consequently promoting the clinical manifestations of this disease. The second disorder is also characterized by deficiency in the a subunit of the Gs protein, but there are no parathormone metabolic changes, although clinical manifestations may occur. ${ }^{16,18,19}$

The phenotypic characteristics present in AHO are: short stature, obesity, round face, shortening of the metacarpus and metatarsus (most frequently the 4 th and $5^{\text {th }}$ ones), calcification in the subcutaneous tissue, short neck, low nasal bridge, mental retardation, cataract, hyperphosphatemia, coneshaped epiphysis, and osteoporo- 
sis. ${ }^{5,8,12,15,20,21}$ When individuals present these changes plus normocalcemia, the disease can be called PPHP, showing that hypocalcemia can be a variable characteristic of this pathogenesis ${ }^{5}$. The oral manifestations found are primarily a late tooth eruption and/or aplasia or hypoplasia of the dental enamel $1^{4,5,8}$.

Laboratory tests of PHP reveal high serum levels of parathormone-concomitantly with hypocalcemia and hyperphosphatemia - and normal renal function. For treatment of these changes, D vitamin and calcium are administered, with periodic checks of calcium serum levels and urinary excretion. Medication can vary due to different clinical and laboratory characteristics. The prognosis of this metabolic disorder is considered good ${ }^{13}$.

In this study, we report a clinical case of AHO and discuss its clinical, radiographic, and laboratory test characteristics together with its oral manifestations, and we correlate them with the characteristics found in the literature. We also discuss the odontological management of treatment of related periodontal disease and planning for corrections of related malocclusions.

\section{CLINICAL CASE REPORT}

A 17-year-old female leucoderma patient was referred to our services, presenting pain and gingival bleeding as the major complaint.

Before the dental clinical procedures, the patient underwent clinical, radiographic, and laboratory tests and genetic evaluation. Tests results showed that the patient had a short stature, obesity, round face, low nasal bridge, short neck, osteoporosis, and motor deficiency due to rheumatoid arthritis in the hand and foot joints (Fig. 1). The presence of subluxations was observed in the joints of the hand with the radius and ulna bones and in the joints of the

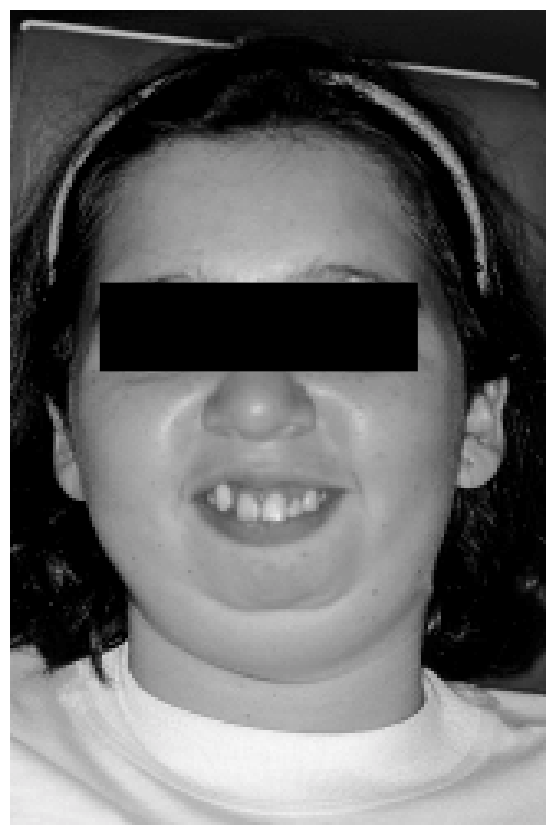

Figure 1 - Patient with Albright hereditary osteodystrophy. Round face, low nasal bridge, and short neck.

metacarpus with the phalanges, as well as shortening of the carpal and tarsal bones, primarily on the $4^{\text {th }}$ metatarsus. Computerized tomography of the lower

limbs showed a valgus deformity of the femur bones and joints and imbalance between the femur and tibia and between the tibia and tarsus, resulting in the left leg being shorter than the right one (Figs. 2 and 3). Laboratory tests showed hypocalcemia, hyperphosphatemia, osteopenia, and endocrine dysfunctions, such as early menarche and hypothyroidism. A genetic evaluation revealed a mutation of a gene lo-

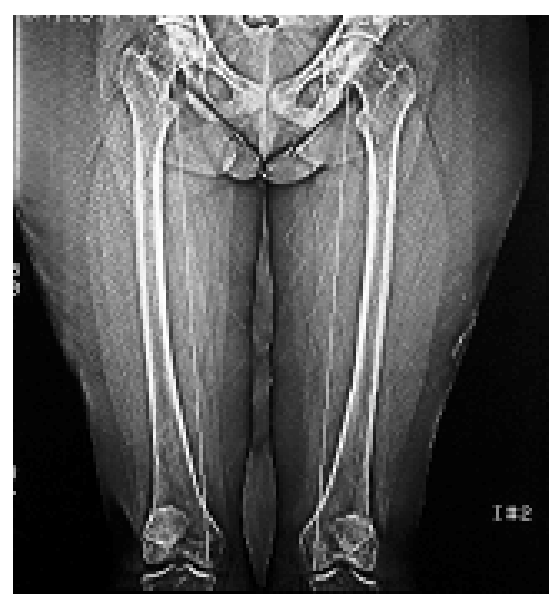

Figure 2 - Femur with valgus deformity.
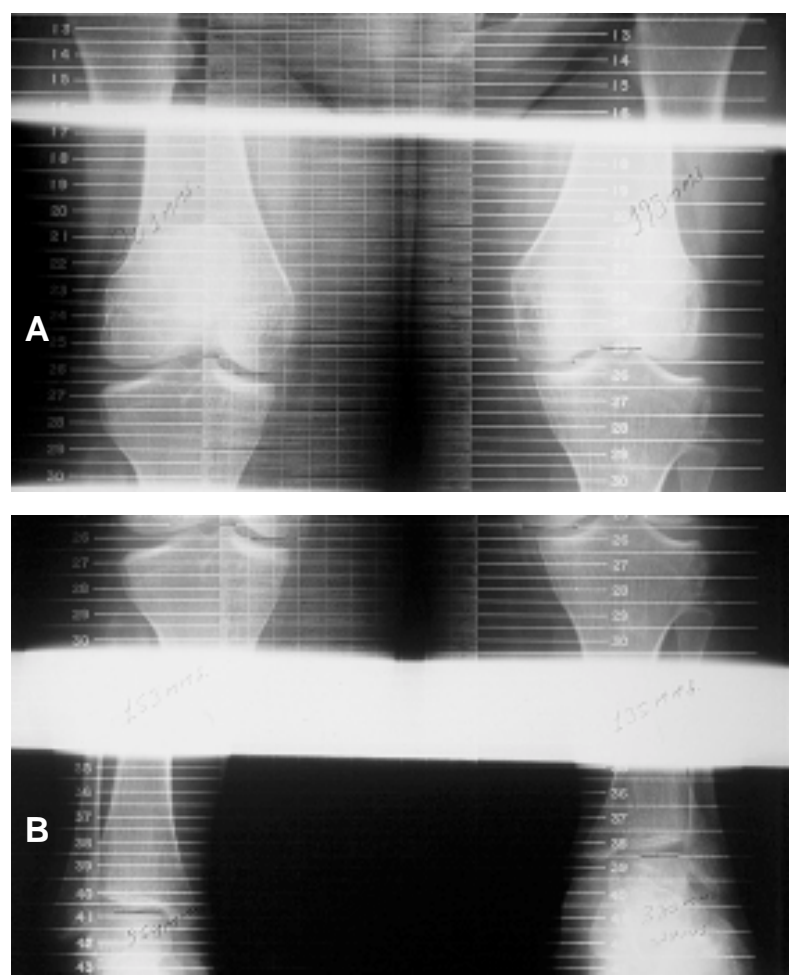

Figure 3 - Imbalanced joints between femur and tibia (A) and between tibia and tarsus (B). 
cated on chromosome 20 in the q13.11 region, establishing a diagnosis of AHO. There was no report in the clinical history of the patient of individuals with AHO in the family.

The extrabuccal clinical exam showed the presence of a factitious lesion on the inferior lip, labial hypotonicity, lack of labial sealing, and crepitation on the temporomandibular joint (TMJ) during opening and closing of the mouth. Panoramic radiographs of the maxillomandibular complex and lateral ones of the cranium and face and of the TMJ showed calvaria thickening, severe open bite at the anterior region (Fig. 4), lack of anodontia and micrognathia, normal chronology of tooth eruption, and occlusion disharmony due to crowding of anterior teeth and superior and inferior premolar teeth (Fig. 5); no signs of any TMJ anatomical abnormalities were seen.

The intrabuccal exam showed deep hard palate, lack of enamel hypoplasia, xerostomia, presence of bacterial plaque on all dental elements, gingival hyperplasia and spontaneous bleeding located primarily in the areas of crowded teeth, predisposing the patient to periodontal disease (Fig. 6).

The patient underwent periodontal treatment and motivation to practice buccal hygiene, with the performance of scaling, planing, and coronary and radicular polishing procedures, fluoride application, and orientation on brushing technique during a period of 2 months with 8 sessions of treatment. After this period, a significant improvement in the clinical picture was observed; the patient was then referred to orthognathous and orthodontic treatments for aesthetic and functional correction of the malocclusion.

\section{DISCUSSION}

In $\mathrm{AHO}$, genetic mutation in the GNAS1 gene of chromosome 20 causes
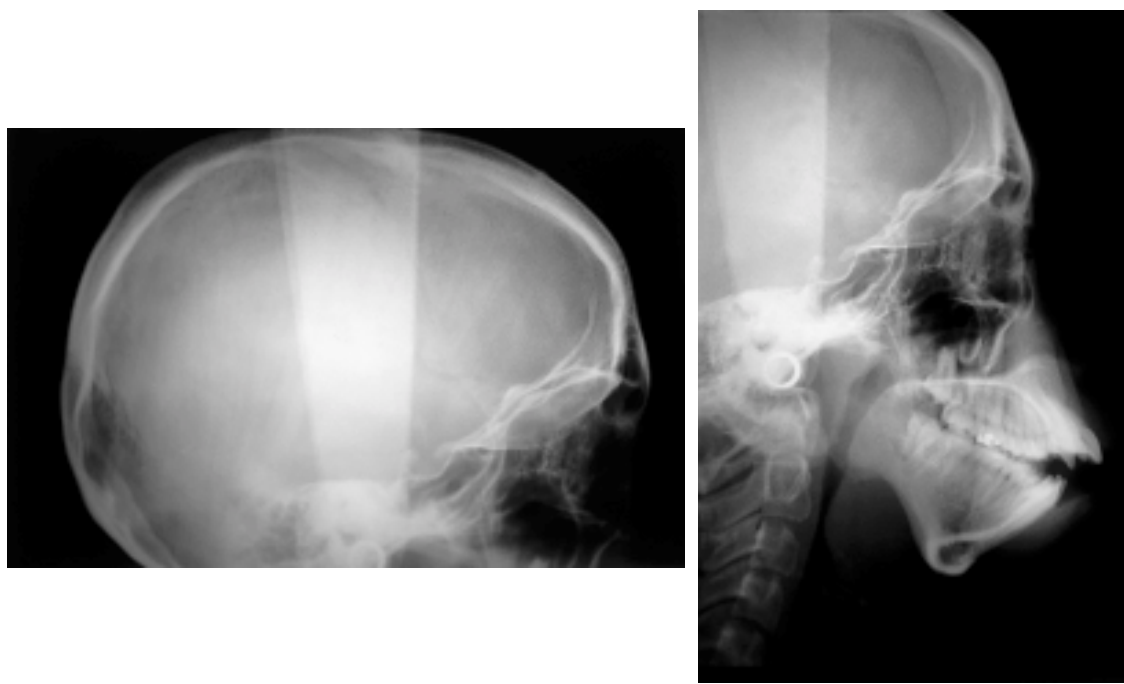

Figure 4 - Lateral radiograph of the cranium and face: (A) calvaria thickening and (B) severe open bite.

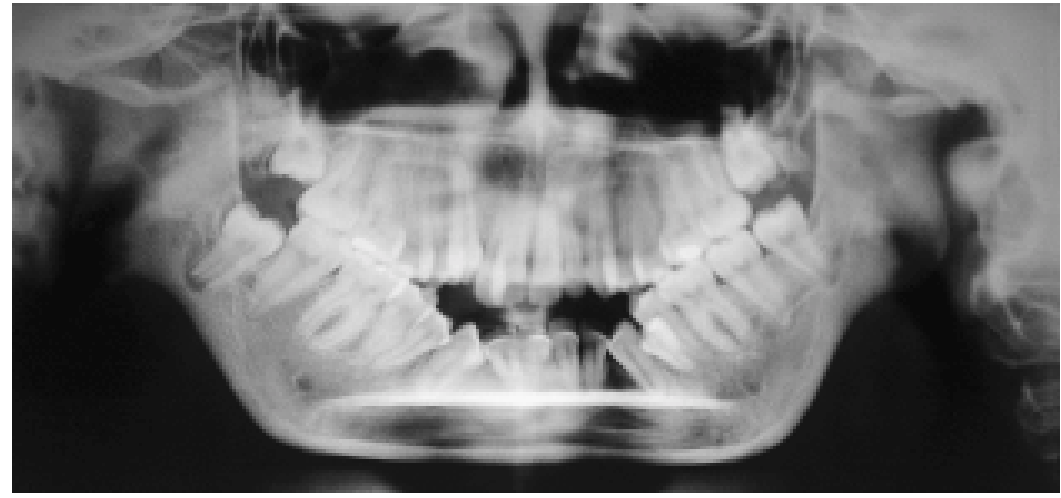

Figure 5 - Panoramic radiograph showing lack of anodontia, unaltered chronology of tooth eruption, and crowded teeth.

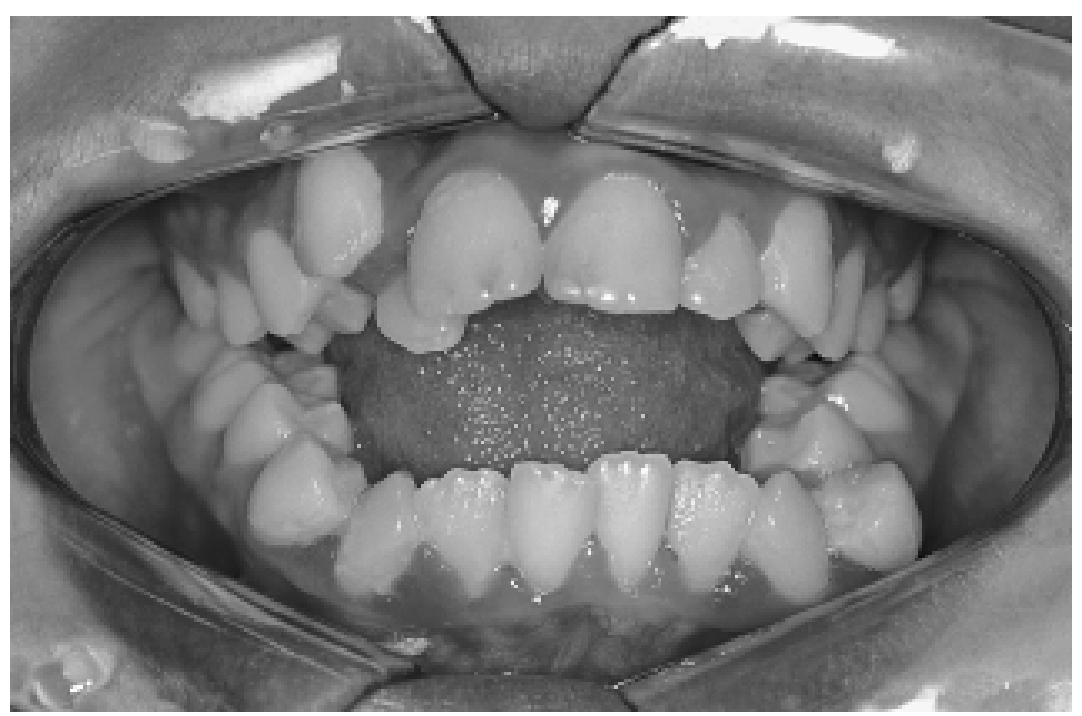

Figure 6 - Clinical intrabuccal exam showing calculus, accumulation of bacterial plaque and areas of spontaneous bleeding at the anterior superior and inferior region. 
a defect in the a subunit of the Gs protein of the cell membrane, resulting in several phenotypic manifestations $^{1,15,17,19}$.

A lack of family history of individuals with $\mathrm{AHO}$ in this study is not contrary to the dominant autosomal heritage type of this disease, as indicated by the sporadic cases described in the literature ${ }^{15,17}$. In our study, we found that the genetic mutation occurred on chromosome 20, which is in accordance with studies reported by Luttikhuis et al. ${ }^{14}$, Jones ${ }^{8}$ and Farfel et al. ${ }^{6}$ These authors observed mutations in the 20q13.11 region of the chromosome $20^{2,8,20}$. Other investigators have also verified deletion in the region 2q37 of chromosome 2, and brachydactyly was one of the phenotypic characteristics of this genetic mutation $^{14-17}$.

The AHO case reported here was classified as subtype Ia pseudohypoparathyroidism, with several mutations in the a subunit of the Gs protein, resulting in loss of function of the Gs protein. This loss of function leads to tissue resistance to multiple hormones whose receptors couple to the Gs protein ${ }^{12,16}$. This genetic disorder manifested clinical signs including obesity and short stature due to hypothyroidism and early menarche. According to Namnoum et al. ${ }^{12}$ menstrual cycle irregularity arises from gonadal hypofunction, promoting a decrease in estrogen secretion.

In this study, other changes were observed, such as round face, shortening of the metacarpus and metatarsus, hypocalcemia, hyperphosphatemia, and mental deficiency, which were also described by Eyre and Reed ${ }^{5}$, Phelan et al. ${ }^{15}$, Williamson et al. ${ }^{21}$, Jones ${ }^{8}$. Namnoum et al. ${ }^{12}$ and Walden et al. ${ }^{20}$ The 4th and 5th metacarpus and metatarsus frequently are the most compromised structures ${ }^{4,5,12,15,20,21}$; however, in our case, only the 4th metacarpus was found compromised.

The subcutaneous calcification at the periarticular regions, mainly located in the hands and feet, are abnormalities found in $50 \%$ of the patients with $\mathrm{AHO}$, as described by Eronocodelu et al. ${ }^{4}$, Eyre and Reed ${ }^{5}$, Jones ${ }^{8}$, Namnoun et al., ${ }^{12}$ Ringel et al. ${ }^{16}$, Miller et al. ${ }^{11}$ and Walden et al. ${ }^{20}$. However, such calcifications were not noted in our study, which is in agreement with findings such as those of Shapira et al. ${ }^{18}$ We agree with Eyre and Reed ${ }^{5}$ that these calcifications arise from metabolic changes concerning calcium and/or phosphorus.

The clinical and radiographic manifestations found in this case, characterized by short stature, round face, moderate obesity, osteoporosis, mental deficiency, and shortening of the carpal and tarsal bones, can be directly and/ or indirectly associated with hypoparathyroidism and hypothyroidism, according to studies conducted by Phelan et al. ${ }^{15}$ Shapira et al. ${ }^{18}$ and Walden et al. ${ }^{20}$ In addition, the presence of juvenile generalized rheumatoid arthritis was noted, which could be indirectly related to $\mathrm{AHO}$.

Goldberg et $\mathrm{al}^{7}$ observed the presence of ankylosis at the temporomandibular joint, but this condition was not present in our case. Since we believe that juvenile rheumatoid arthritis together with an occlusal disharmony could cause TMJ disease, we conducted a more thorough investigation of this region.

The oral manifestations of AHO found in the literature include aplasia and/or enamel hypoplasia, late tooth eruption, and enlarged radicular channels susceptible to caries. Such manifestations were not observed in our study. However, we observed the presence of severe periodontal disease with gingivitis and severe chronic peri- odontitis. An intense inflammatory process was also observed located in the region of the superior and inferior anterior teeth, clinically characterized by spontaneous bleeding, pain, and gingival hyperplasia. In addition, there was also the presence of crowded superior and inferior anterior teeth, impairing proper buccal hygiene and favoring the accumulation of bacterial plaque and calculus.

The labial hypotonicity, deep hard palate, and xerostomia found in this case were changes probably resulting from the fact that the patient was a buccal respirator. In no work from the literature was any correlation between that respiratory dysfunction and $\mathrm{AHO}$ reported. Also, we believe that the motor deficiency resulted from rheumatoid arthritis, impairing buccal hygiene and favoring the accumulation of bacterial plaque and the persistence of periodontal disease.

The findings of general and oral manifestations of AHO described in our report contribute to the clinical picture of AHO that is developing in the literature. Extrabuccal and intrabuccal changes in patients with $\mathrm{AHO}$ continue to be the object of many studies, since there is little information on the oral manifestations of this disease, which hinders a better understanding of possible correlations between metabolic dysfunctions and oral manifestations. The findings of this study could also facilitate the development of a multidisciplinary approach among medical and dental professionals to promote a more precise diagnosis and knowledge of AHO behavior in the region of the face and the maxillomandibular complex. This more precise diagnosis and knowledge of AHO behavior could facilitate better planning of dental treatment of these patients, with a positive effect on their general health. 
GOMES MF e col. - Osteodistrofia Hereditária de Albright: relato das manifestações bucais de um caso. Rev. Hosp. Clín. Fac. Med. S. Paulo 57(4):161-166, 2002.

A Osteodistrofia Hereditária de Albright é uma desordem metabólica de caráter hereditário, de etiologia autossômica dominante, caracterizada geralmente por baixa estatura, face ar- redondada, metacarpos e metatarsos pequenos, retardo mental, osteoporose, calcificações subcutâneas, hipocalcemia e hiperfosfatemia variáveis. Neste estudo, relatamos um caso clínico de uma jovem de 17 anos com Osterodistrofia Hereditária de Albright e discutimos as suas características clínicas, radiográficas, laboratoriais e manifestações bucais, relacionando-as com as encontradas na literatura, bem como a conduta odontológica pertinente ao tratamento de doenças periodontais e ao planejamento da correção das más oclusões existentes.

DESCRITORES: Osteodistrofia Hereditária de Albright. Pseudohipoparatiroidismo. Proteína Gs. Paratormônio. Manifestações bucais.

\section{REFERENCES}

1. AHMED SF, DIXON PH, BONTHRON DT et al - GNAS1 mutational analysis in pseudohypoparathyroidism. Clin Endocrinol (Oxf) 1998; 49: 525-31.

2. DAVIES SJ \& HUGHES HE - Imprinting in Albright's hereditary osteodystrophy. J Med Genet 1993; 30: 101-3.

3. DOTY RL, FERNANDEZ AD, LEVINE MA et al - Olfactory dysfunction in type I pseudohypoparathyroidism: dissociation from Gs alpha protein deficiency. J Clin Endocrinol Metab 1997; 82: 247-50.

4. ERONOCODELU Y, BÖBER AND \& TUNNESSEN JR WW Picture of the month. Albright hereditary osteodystrophy. Arch Pediatr Adolesc Med 1997; 151: 1263-4.

5. EYRE WG \& REED WD - Albright's hereditary osteodystrophy with cutaneous bone formation. Arch Dermatol 1971; 104: 634-42.

6. FARFEL Z, BOURNE HR \& IIRI T - The expanding spectrum of G protein diseases. N Engl J Med 1999; 340: 1012-20.
7. GOLDBERG MH, SLAUGHTER TW \& HARRIGAN WF Pseudohypoparathyroidism with temporo-mandibular ankylosis: report of case. J Oral Surg 1967; 25:175-81.

8. JONES KL - Smith's Recognizable Patterns of Human Malformation. In: (book author) Albright hereditary osteodystrophy. São Paulo, Ed. Manole, 1998. p. 846.

9. JUPPNER $\mathrm{H}$ - The gene responsible for pseudohypoparathyroidism type $\mathrm{Ib}$ is paternally imprinted and maps in four unrelated kindreds to chromosome 20q13.3. Proc Natl Acad Sci U S A 1998; 95: 11798-803.

10.KAWAKAMI A, NAGASAKA S, ROKKAKU $\mathrm{K}$ et al Pseudohypoparathyroidism, obesity, and type 2 diabetes. A hypothesis. Diabetes Care 1999; 22: 523.

11.MILLER ES, ESTERLY NB \& FAIRLEY JA - Progressive osseous heteroplasia. Arch Dermatol Res 1996; 132: 787-91.

12.NAMNOUM AB, MERRIAM GR, MOSES AM et al - Reproductive dysfunction in women with Albright's hereditary osteodystrophy. J Clin Endocrinol Metab 1998; 83: 824-9. 
13.NEVILLE, B.W., DAMM, D.D., ALLEN, C.M. et al - Oral $\&$ Maxillofacial Pathology. Philadelphia, W.B. Saunders Company, 1995. p. 611.

14.OUDE LUTTIKHUIS MEM, WILLIAMS DK \& TREMBATH RC - Isolated autosomal dominant type and brachydactyly: exclusion of linkage to candidate regions $2 \mathrm{q} 37$ and $20 \mathrm{q} 13$. J Med Genet 1996; 33: 873-6.

15.PHELAN MC, ROGERS RC, CLARKSON KB et al - Albright hereditary osteodystrophy and $\operatorname{del}(2)(\mathrm{q} 37.3)$ in four unrelated individuals. Am J Med Genet 1995; 58: 1-7.

16.RINGEL HD, SCHWINDINGER WF \& LEVINE MA - Clinical implications of genetic defects in G proteins. Medicine (Baltimore) 1996; 75: 171-84.

17.SAKAGUCHI H, SANKE T, AHOGI S et al - A case of Albright's hereditary osteodystrophy-like syndrome complicated by several endocrinopathies: normal Gs alpha gene and chromosome $2 \mathrm{q} 37$. J Clin Endocrinol Metab 1998; 83: 1563-5.
18.SHAPIRA H, FRIEDMAN AND, MOUALLEM M et al - Familial Albright's hereditary osteodystrophy with hypoparathyroidism: normal structural Gs alpha gene. J Clin Endocrinol Metab 1996; 81: 1660-2.

19.SPIEGEL AM - The molecular basis of disorders caused by defects in G proteins. Horm Res 1997; 47: 89-96.

20.WALDEN U, WEISSÖRTEL R, CORRIA Z et al - Stimulatory guanine nucleotide binding protein subunit 1 mutation in two siblings with pseudohypoparathyroidism type 1a and mother with pseudopseudohypoparathyroidism. Eur J Pediatr 1999; 158: $200-3$.

21.WILLIAMSON CM, SCHOFIELD J, DUTTON ER et al Glomerular - specific imprinting of the mouse Gs alpha gene: How does this relate to hormone resistance in Albright hereditary osteodystrophy? Genomics 1996; 36: 280-7.

Received for publication on March 20, 2001 